Al-Madrasah: Jurnal Ilmiah Pendidikan Madrasah Ibtidaiyah

Vol. 6, No. 1, 2022

DOI 10.35931/am.v6i1.842

P-ISSN: 2620-5807; E-ISSN: 2620-7184

\title{
PENERAPAN MEDIA KOPI DENGAN STRATEGI KRIPIK UNTUK MENINGKATKAN KEMAMPUAN MENULIS DI SDN SEMANGAT DALAM 2 HANDIL BAKTI
}

\author{
Tutus Rani Arifa ${ }^{1}$, Sari Kumala, Barsihanor \\ ${ }^{1,2}$ Dosen PGMI, Fakultas Studi Islam Universitas Islam \\ Kalimantan Mab Banjarmasin \\ tutusuniska17@gmail.com
}

\begin{abstract}
Abstrak
Tujuan dalam penelitian ini adalah untuk mengetahui bagaimana penerapan kemampuan menulis siswa kelas II di SDN Semangat Dalam 2 Handil Bakti Barito Kuala, dengan diterapkannya media kopi strategi kripik pada proses pembelajaran. Dalam hal ini KOPI itu merupakan singkatan dari KO $=$ Kotak PI $=$ PIntar. Sedangkan KRIPIK dari akronim $K=$ Kenlai, $R=$ Rencanakan, $I=$ Implematasikan, $P I=$ Pintar dan $K=$ Kontinyu. Rumsan masalah dalam penelitian ialah: 1) Bagaimana penerapan Media Kopi dengan strategi kripik dalam kemampuan menulis di SDN Semangat Dalam 2 Handil Bakti, 2) Apakah penerapan media kopi dengan strategi kripik dapat meningkatkan kemampuan menulis cerita di SDN Semangat Dalam 2 Handil Bakti. Metode yang digunakan dalam penelitian ialah kulaitatif deskriptif. Adapun hasil dalam penelitian ini mendapatkan peningkatan keterampilan menulis di SDN Semangat Dalam 2 Handil Bakti. Dilihat dari indikator yang menunjukkan hasil rata-rata kemampuan dan keaktifan dengan kategori $B$ (baik). Siswa yang mendapat perlakuan dari 31 orang dengan rincian 4 siswa mendapat kategori mulai berkembang, 18 siswa berkembang sesuai harapan dan 9 siswa berkembang sangat baik. Dengan bukti siswa mampu menunjukkan kenaikan kemampuan menulis cerita dan mencapai ketuntasan.
\end{abstract}

Kata kunci : Media Kopi, Strategi Kripik, Kemampuan Menulis Cerita

\section{PENDAHULUAN}

Pelajaran bahasa Indonesia di sekolah dengan tujuan agar bisa mengembangkan pengetahuan siswa, kemampuan berbahasa siswa dan agar siswa memiliki sikap positif terhadap bahasa Indonesi. ${ }^{1}$ Maka pelajaran bahasa dan satra Indonesia sangat berperan untuk mengmbangkan kemampuan siswa dalam berinteksi sosial melalui lisan dan tulisan.

Sebagian hal penting yang wajib dimiliki siswa ialah kemampuan membaca sebagai dasar dalam pembelajaran. Mampunya siswa dalam hal membaca harus didasari karena diajari, bukan karena ketidak sengajaan (kebetulan) ataupun karena dorongan inspirasi. Karena membaca itu

1 "Pendidikan PAUD Tim Penyusun, 2002. Kamus Besar Bahasa Permendikbud No 137 Tahun 2014 Tentang Standar Nasional," t.t.

Al-Madrasah: Jurnal Ilmiah Pendidikan Madrasah Ibtidaiyah Vol. 6, No. 1, Januari-Maret 2022 
Tutus Rani Arifa, Sari Kumala, Barsihanor : Penerapan Media Kopi Dengan Strategi Kripik Untuk Meningkatkan Kemampuan Menulis di SDN Semangat Dalam 2 Handil Bakti

bukanlah pekerjaan yang alamiah, akan tetapi merupakan kemampuan yang harus terus diasah hingga menjadi terintegrasi dan mahir dengan kebiasaan. ${ }^{1}$

Saat proses belajar terkadang siswa menemukan rasa nikmat ketika membaca tidak hanya sebagai keadaan diwaktu bisa memecahkan kode, namun lebih kepada terasa mendapatkan pengetahuan dan kebahagiaan. ${ }^{2}$ Hingga nantinya siswa dikemudian hari akan menjadi lebih tenang, santai dan matang karena banyaknya pengetahuan yang dimiliki yang didapat melalui aktifitas membaca. Dalam hal ini bacaannya bukan hanya saja tentang buku yang berwujud fiksi, akan tetapi juga buku yang berupa non fiksi. Dilihat dari sudut pandang anak besar kemungkinan akan menemukan kebahagiaan namun sangat bergantung pada asuhan dan arahan dari para orang tua dan pendidik. ${ }^{3}$

Kemampuan menulis merupakan bagian dari proses agar bisa paham makna dalam sebuah tulisan. Agar pemahamnnya menjadi sempurna maka harus melalui step mengenal huruf, mengenal kata, mengenal frase, mengenal kalimat, wacana serta menyambungnya dengan bunyi dan makna. Lebih jauh lagi agar bertambah pemahanan, maka pembaca harus menghubungkan pengalaman dengan apa yang dibaca. ${ }^{4}$

\section{METODE PENELITIAN}

Penelitian ini menggunakan metode kualitatif deskriptif. Kualititif deskriptif merupakan prosedur penelitian yang mnghasilkan data dalam bentuk deskriftif (kata-kata) tertulis maupun lisan dari orang-orang dan perilaku yang dapat diamati dari sumber data. ${ }^{6}$ Pelaksanaan dalam penelitian ini ialah dengan cara mengambangkan bahan-bahan pengumpulan data yang sesuai dengan tujuan penelitian yang telah ditetapkan, agar mencari dan mendapatkan data yang diperlukan. Kemudian data yang telah diperoleh dikumpulkan dari berbagai macam teknik seperti observasi, wawancara dan dokumentasi.

\subsection{Lokasi Penelitian}

Penelitian ini dilakukan di SDN Semangat Dalam 2 Handil Bakti

\subsection{Data dan Sumber Data}

Menjadi objek dalam penelitian ialah kemampuan menulis cerita yang diolah siswa. Pemilihan tersebut dimaksudkan untuk merangsang nalar imajinasi siswa ketika menulis. Sampel yang digunakan dalam penelitian ini berjumlah 31 siswa dari kelas II. Penelitan dimaksudkan

\footnotetext{
${ }^{1}$ Mohammad Adhim Fauzil, Membuat Ankan Gila Memaca (Bandung: Mizan Pustaka, 2004).

${ }^{2}$ Desmita, Psikologi Perkembangan (Bandung: Remaja Rosda Karya, 2005).

${ }^{3}$ Francoice Grellet, Developing Reading Skill (USA: Cambridge, 1986).

${ }^{4}$ Farida Rahim, Pengajaran Membaca di Sekolah Dasar (Jakarta: PT Bumi Aksara, 2005). Rineka Cipta, 2010).

6 Suharsimi Arikunto, Prosedur Penelitian Suatu Pendekatan Praktis (Jakarta:
} 
Tutus Rani Arifa, Sari Kumala, Barsihanor : Penerapan Media Kopi Dengan Strategi Kripik Untuk Meningkatkan Kemampuan Menulis di SDN Semangat Dalam 2 Handil Bakti

untuk mengetahui kemampuan siswa dalam menulis cerita di SDN Semangat Dalam 2 Handil

Bakti. Teknik data yang terkumpul akan diolah sebagai berikut:

a. Data hasil observasi diperoleh berdasarkan kunjungan langsung pada lokasi penelitian. Dianalisis berdasarkan data yang diperoleh hingga akurat dan asli, agar fakta yang sebenarnya dapat terungkap secara cermat dan menyeluruh. Beberapa data tersebut ialah data hasil teknik tes, yang digunakan untuk mengetahui keterampilan siswa dalam menulis karangan persuasi, saat siswa melihat tanyangan dari media gambar. Siswa diharapkan bisa menulis karangan persuasi sebanyak 2 paragraf atau lebih, agar bisa menjawab apakah media tersebut dapat merangsang imajinasi siswa atau tidak. Setelahnya data yang didapat akan dijadikan satu untuk mendapatkan kesimpulan.

b. Imajinasi siswa atau tidak. Data yang didapat berikutnya dijadikan satu dan diambil kesimpulan.

c. Analisis data dengan teknik tes yang menjadi objek dalam penelitian ialah siswa pada kelas II SDN Semangat Dalam 2 Handil Bakti dengan jumlah keseluruhan 31 siswa. peserta didik dalam kemampuan menulis cerita.

\section{HASIL DAN PEMBAHASAN}

Kontribusi dalam media KOPI dapat meningkatkan motivasi siswa ketika menulis cerita. Di sisi lain siswa dapat mengurutkan gambar yang sudah disediakan sesuai dengan konteks yang ada pada gambar. Menggunakan media gambar perhatian siswa menjadi lebih terfokus dengan satu pembahasan yang dijelaskan oleh guru. Akhirnya media KOPI menjadi pembelajaran yang efektif. $^{7}$

Pembuatan kotak bahannya beraneka ragam mulai dari kertas karton yang berbahan ringan, mudah didapat dan penggunaannya bisa untuk menyimpan barang-barang yang ringan. Ada juga bahan yang lebih berat seperti dari kayu dan penggunaannya untuk menyimpan barang-barang berat. Pintar ialah mengetahui, pandai dan memiliki ilmu. Pintar dibatasi oleh waktu dan proses dan tahapan untuk mempelajari suatu hal terlebih dahulu dengan jangka waktu tertentu sampai akhirnya ia mengetahui sepenuhnya akan hal yang dipelajarinya tersebut.

Media KOPI membagikan andil yang baik terhadap siswa agar mampu memajukan motivasi siswa saat menulis cerita. Adapun kemampuan siswa yang bisa di angkat ialah dapat mengurutkan gambar termaktub sesuai dengan konteks yang tersedia dalam gambar. Memakai media gambar,

\footnotetext{
${ }^{7}$ Dhieni dkk., Metode Pengembangan Bahasa (Jakarta: Universitas Terbuka, 2008).
} 
Tutus Rani Arifa, Sari Kumala, Barsihanor : Penerapan Media Kopi Dengan Strategi Kripik Untuk Meningkatkan Kemampuan Menulis di SDN Semangat Dalam 2 Handil Bakti

siswa dapat terpusat perhatiannya di satu pembahasan yang diberikan oleh guru, akhirnya media gambar seri menjadi pembelajaran yang efektif. ${ }^{8}$

Menurut Wina Senjay," mengemukakan bahwa "strategi pembelajaran adalah suatu kegiatan pembelajaran yang harus dikerjakan guru dan siswa agar tujuan pembelajaran dapat dicapai secara efektif dan efisien". Perencanaan merupakan bagian dari strategi pembelajaran, yang menjelaskan bahwa strategi masih bersifat konseptual tentang keputusan-keputusan yang akan dieksekusi saat melaksanakan pembelajaran. Jadi, strategi pembelajaran ialah rencana tindakan (rangkaian kegiatan) yang didalamnya terdapat metode, pemanfaatan sumber daya kekuatan didalam pembelajaran. Manfaat strategi untuk dapat mencapai tujuan dalam pembelajaran. Dengan demikian arah menuju keberhasilan pembelajaran bisa dilihat dari penyusunan strateginya.

KRIPIK ialah singkatan dari Kenali, Rencanakan, Implementasikan, Penilaian, dan Kontinyu (berkesinambungan). ${ }^{10}$ Adapaun komponen dari KRIPIK ialah: Kenali. Kenali merupakan bahasa yang digunakan untuk mengenal karakteristik siswa, materi yang akan diajarkan, bahan ajar yang digunakan, media yang dipakai, lingkungan sekitar dan sebagainya. Rencanakan merupakan bagian dari merencanakan materi yang akan diajarkan, terus melihat media yang akan digunakan apakah sudah sesuai atau tidak. Implementasi merupakan tindak lanjut dari apa yang telah direncanakan sebelumnya. Penilaian merupakan pemberian nilai secara otentik yang sesuai dengan tujuan pembelajaran. Kontinyu merupakan kegiatan yang menggunakan media kota pintar dengan cara berkelanjutan serta menggunakan penilaian berkelanjutan dalam kegiatan media KOPI

Hasil dalam penerapan media KOPI dengan Strategi KRIPIK agar dapat meningkatkan kemampuan menulis di SDN Semangat Dalam 2 Handil Bakti di kelas II didapat bahwa dari 31 siswa seluruhnya ada 4 siswa mendapat hasil dengan mulai berkembang, 18 siswa mendapati hasil berkembang sesuai dengan harapan dan 9 siswa dengan hasil berkembang sangat baik. Dapatlah disimpulkan bahwa adanya peningkatan kemampuan menulis cerita dan sudah mencapai ketuntasan.

\section{KESIMPULAN}

Berlandaskan dengan pembahasan yang telah dilakukan di atas maka dapat kita ambil kesimpulan bahwa, dalam pengaplikasian media KOPI dengan strategi KRIPIK mendapatkan

\footnotetext{
${ }^{8}$ A Muhyidin, "Metode Pembelajaran Membaca dan Menulis Permulaan di Kelas Awal," JPSD 4, no. 1 (Maret 2018): 30-42.

${ }^{9}$ Wina Sanjaya, Strategi Pembelajaran (Jakarta: Bumi Aksara, 2008).

10 Susanti, Perkembangan Anak Usia Dini: Pengantar dalam berbagai Aspeknya (Jakarta: Kencana Prenada Media Group, t.t.).
} 
Tutus Rani Arifa, Sari Kumala, Barsihanor : Penerapan Media Kopi Dengan Strategi Kripik Untuk Meningkatkan Kemampuan Menulis di SDN Semangat Dalam 2 Handil Bakti

hasil: dapat meningkatkan kemampuan menulis cerita pada siswa kelas II di SDN Semangat Dalam 2 Handil Bakti tahun pelajaran 2019/2020. Oleh karena itu, bisa ditarik kesimpulan media ini berhasil dan dapat dianjurkan kepada semua stake holder supaya ikut mendukung dalam pengaplikasian media KOPI dengan strategi KRIPIK agar bisa meningkatkan kemampuan menulis cerita pada siswa kelas II di SDN Semangat Dalam 2 Handil Bakti.

\section{DAFTAR PUSTAKA}

A Muhyidin. "Metode Pembelajaran Membaca dan MenulisPermulaan di Kelas Awal." JPSD 4, no. 1 (Maret 2018): 30-42.

Adhim Fauzil, Mohammad. Membuat Ankan Gila Memaca. Bandung: Mizan Pustaka, 2004.

Arikunto, Suharsimi. Prosedur Penelitian Suatu Pendekatan Praktis. Jakarta: Rineka Cipta, 2010.

Desmita. Psikologi Perkembangan. Bandung: Remaja Rosda Karya, 2005.

Dhieni, Nurbiana, Lara Fridani, Gusti Yarmi, dan Nany Kusniaty.Metode Pengembangan B ahasa. Jakarta: Universitas Terbuka, 2008.

Grellet, Francoice. Developing Reading Skill. USA: Cambridge, 1986.

"Pendidikan PAUD Tim Penyusun, 2002. Kamus Besar Bahasa Permendikbud No 137 Tahun 2014 Tentang Standar Nasional," t.t.

Rahim, Farida. Pengajaran Membaca di Sekolah Dasar. Jakarta: PT Bumi Aksara, 2005.

Sanjaya, Wina. Strategi Pembelajaran. Jakarta: Bumi Aksara, 2008.

Susanti. Perkembangan Anak Usia Dini: Pengantar dalam berbagai Aspeknya. Jakarta: Kencana Prenada Media Group, t.t. 